\title{
SPRAY DRIFT AND EFFICACY FROM GLYPHOSATE AND 2,4-D APPLICATIONS WITH ADJUVANTS
}

\author{
DERIVA E EFICÁCIA DE APLICAÇÕES DE GLIFOSATE E 2,4-D COM \\ ADJUVANTES
}

\section{Guilherme Sousa ALVES ${ }^{1}$; João Paulo Arantes Rodrigues da CUNHA ${ }^{2}$; Thiago Nunes LANDIM ${ }^{3}$; Sérgio Macedo SILVA ${ }^{4}$; Thales Cassemiro ALVES ${ }^{5}$; Caio Silva GOULART ${ }^{6}$}

1. Pós-Doutorando, Universidade de Nebraska, Lincoln, EUA, guilherme.alves@unl.edu; 2. Professor, Universidade Federal de Uberlândia, Instituto de Ciências Agrárias, Uberlândia, MG, Brasil. 3. Mestre em Agronomia, Universidade Federal de Uberlândia, Instituto de Ciências Agrárias, Uberlândia, MG, Brasil; 4. Professor, Universidade Federal dos Vales do Jequitinhonha e Mucuri, Unaí, MG, Brasil; 5. Doutorando, Universidade Federal de Uberlândia, Instituto de Ciências Agrárias, Uberlândia, MG, Brasil; 6. Graduado em Agronomia, Universidade Federal de Uberlândia, Instituto de Ciências Agrárias, Uberlândia, MG, Brasil.

\begin{abstract}
Weed plants are one of main factors that affect the production of oilseed crops. Their management have been based on chemical control with herbicides, like glyphosate and 2,4-D, due to usefulness and efficiency of applications. However, their use must be managed correctly to mitigate the spray drift. Therefore, this study aimed to evaluate efficacy and spray drift from glyphosate and 2,4-D applications with adjuvants. The drift evaluation of herbicide solutions was conducted in a split-plot arranged in a randomized block design with five replications. Main plots consisted of three herbicide solutions at $150 \mathrm{~L} \mathrm{ha}^{-1}$ (glyphosate + 2,4-D, glyphosate + 2,4-D + sodium lauryl ether sulphate, and glyphosate + 2,4-D + fatty acid esters). Sub-plots consisted of five downwind distances $(1$ to $10 \mathrm{~m})$ from the sprayed area. It was used a fluorecent tracer and drift colectors. The efficacy trial was performed in a randomized block design with four replications in a 3 x 2 factorial scheme, being the same herbicide solutions and two carrier volumes ( 75 and $150 \mathrm{~L} \mathrm{ha}^{-1}$ ). Droplet spectrum and weed depositon were evaluated and physicochemical properties of the herbicide solutions were characterized. Glyphosate + 2,4-D with or without adjuvants, sprayed using 75 or $150 \mathrm{~L} \mathrm{ha}^{-1}$, resulted in similar deposition of tracer on weeds and their control. Those herbicides associated or not with sodium lauryl ether sulphate and fatty acid esters produce similar droplet spectrum and deposition of tracer on drift collectors.
\end{abstract}

KEYWORDS: Additives. Herbicide. Application technology.

\section{INTRODUCTION}

Soybean (Glycine max (L.) Merrill) is the most important oilseed crop produced worldwide, subjected to many factors that affect its development and production. Among those factors, weeds have decreased yields due to competition for light, nutrients, and water; beyond problems in harvesting process (NEPOMUCENO et al., 2007). Weed management have been based on chemical control with herbicides due to usefulness, efficiency and agility of applications. With recent development of new glyphosate and 2,4-D-resistant crops, their use will increase in the next few years (ROBINSON; SIMPSON; JOHNSON, 2012), as well as concerns about environmental contamination. Specifically for $2,4-\mathrm{D}$, it must be managed correctly to mitigate spray drift, e.g., do not spray it close to sensitive areas and under inadequate wind speed conditions (GANDOLFO et al., 2012; COSTA et al., 2014).
Pesticide spray drift has caused many
problems in agriculture (VERCRUYSSE; STEURBAUT, 2002; TSAI, 2005). Some authors showed that from $10 \%$ up to $80 \%$ of products sprayed on crops are lost to non-target areas, contaminating superficial and underground water, soil and atmosphere (JONG; SNOO; ZANDE, 2008; MASKI; DURAIRAJ, 2010). An important tool that may be helpful to mitigate pesticide spray drift is the adjuvants. Their drift-reducing properties depend on interaction with active ingredient and pesticide formulation (CUNHA; ALVES; MARQUES, 2017). For this reason, they have to be analysed at each situation.

Therefore, this study aimed to evaluate efficacy and spray drift from glyphosate and 2,4-D applications using two different adjuvants and carrier volumes. 


\section{MATERIAL AND METHODS}

Fields experiments were conducted at the Capim Branco Farm of the Federal University of Uberlandia in Uberlandia, MG, Brazil (18 53'23.46"S 48²0'27.46"W).

\section{Drift evaluations}

Applications were performed on soybean crop, not resistant to 2,4-D (Nidera Sementes Ltda, NS 6906 RR2 IPRO, Uberlândia, MG, Brazil), planted in $50 \mathrm{~cm}$-wide-rows and population of 360,000 plants $\mathrm{ha}^{-1}$. During the applications, the crop was at V5/V6 stage. The experimental design was a split-plot arranged in a randomized block design with five replications. Main plots and subplots consisted of three herbicide solutions and five downwind distances from the sprayed area $(1,2,3$, 5 , and $10 \mathrm{~m}$ ), respectively. Herbicide solution (HS) included glyphosate and 2,4-D in a premix formulation (glyphosate, dimethylammonium salt + 2,4-Dichlorophenoxyacetic acid, choline salt, 1025 $\mathrm{g}+975 \mathrm{~g}$ acid equivalent $\mathrm{ha}^{-1}$ ), without and with two adjuvants (sles - sodium lauryl ether sulphate at
$0.05 \% \mathrm{v} \mathrm{v} \mathrm{v}^{-1}$ and fae - fatty acid esters at $0.125 \% \mathrm{v} \mathrm{v}^{-}$

$\left.{ }^{1}\right)$. A fluorescent brilliant sulfoflavine tracer (Biovalley, Marne La Vallee, France) was added in solutions at $5 \mathrm{~g} \mathrm{~L}^{-1}$ to be afterwards detected by fluorimetry in laboratory.

A $\mathrm{CO}_{2}$-operated manual backpack sprayer was used and calibrated to apply $150 \mathrm{~L} \mathrm{ha}^{-1}$ at 260 $\mathrm{kPa}$ pressure and $4.4 \mathrm{~km} \mathrm{~h}^{-1}$ travel speed. The boom had six AIXR 110015 nozzles (Spraying Systems Co., Wheaton, IL, USA), spaced $0.5 \mathrm{~m}$ apart. The boom height was maintained at $0.5 \mathrm{~m}$ above the canopy. The sprayed area had dimensions of $20 \times 6$ $\mathrm{m}$, consisted of $20-\mathrm{m}$ driveline and two passes of sprayer. The driveline was setup perpendicularly to the ideal wind direction. Wind direction, wind speed, air temperature, and relative humidity data were monitored using a weather station (Davis Instruments Corp. Inc., Vantage PRO2, Vernon Hills, IL, USA), positioned close to the sprayed area. The meteorological conditons during the applications are presented in Table 1. The Northeast wind direction was considered the ideal direction for being perpendicular to the driveline.

Table 1. Meteorological conditions during field spray applications.

\begin{tabular}{|c|c|c|c|c|c|}
\hline Block & Solution $^{1}$ & Hour & Wind speed & Temperature & $\begin{array}{l}\text { Relative } \\
\text { humidity }\end{array}$ \\
\hline \multirow{4}{*}{1} & & -h am- & $--\mathrm{m} \mathrm{s}^{-1}--$ & --- ${ }^{\circ} \mathrm{C}---$ & ----\%"-- \\
\hline & HS & $9: 05$ & 3.6 & 23.7 & 81 \\
\hline & $\mathrm{HS}+$ sles & $9: 24$ & 4.9 & 24.1 & 78 \\
\hline & $\mathrm{HS}+\mathrm{fae}$ & $9: 30$ & 4.0 & 24.2 & 79 \\
\hline \multirow[t]{3}{*}{2} & $\mathrm{HS}$ & $9: 40$ & 4.0 & 24.4 & 78 \\
\hline & $\mathrm{HS}+$ sles & $9: 57$ & 4.0 & 24.8 & 77 \\
\hline & $\mathrm{HS}+\mathrm{fae}$ & $10: 03$ & 4.0 & 25.0 & 77 \\
\hline \multirow[t]{3}{*}{3} & $\mathrm{HS}$ & $10: 08$ & 4.0 & 24.9 & 77 \\
\hline & $\mathrm{HS}+$ sles & $10: 20$ & 4.5 & 24.8 & 75 \\
\hline & $\mathrm{HS}+\mathrm{fae}$ & $10: 25$ & 4.0 & 25.1 & 76 \\
\hline \multirow[t]{3}{*}{4} & $\mathrm{HS}$ & $10: 38$ & 3.6 & 25.7 & 73 \\
\hline & $\mathrm{HS}+$ sles & $10: 50$ & 4.5 & 26.0 & 70 \\
\hline & $\mathrm{HS}+\mathrm{fae}$ & $10: 56$ & 3.6 & 26.1 & 72 \\
\hline \multirow[t]{3}{*}{5} & $\mathrm{HS}$ & $11: 02$ & 4.5 & 26.1 & 71 \\
\hline & $\mathrm{HS}+$ sles & $11: 13$ & 3.1 & 25.8 & 73 \\
\hline & $\mathrm{HS}+\mathrm{fae}$ & $11: 17$ & 3.1 & 25.9 & 72 \\
\hline
\end{tabular}

${ }^{1}$ HS: glyphosate + 2,4-D; sles: sodium lauryl ether sulphate; fae: fatty acid esters.

Drift collectors consisted of blotting papers (JProlab, São José dos Pinhais, PR, Brazil) with dimensions of $0.38 \times 0.07 \mathrm{~m}$ were fixed onto polyethylene plates positioned on the ground at each downwind distance perpendicularly to the driveline. Collectors were placed in three separate lines, spaced at $1.5 \mathrm{~m}$ at each distance. Once spraying was complete, the papers were collected and stowed individually into a pre-labeled plastic bag and then placed into a heat- and light-insulated container to prevent photodegradation of the tracer until fluorimetric analysis could be conducted. In the laboratory, a $100 \mathrm{~mL}$ of distilled water was added to each plastic bag, which was subjected to constant 
agitation at 120 rotations per minute for $15 \mathrm{~min}$ on a pendulum shaker (Tecnal, TE240/I, Piracicaba, SP, Brazil). The samples were left to rest for $10 \mathrm{~min}$. After the tracer was suspended in solution, a $3 \mathrm{~mL}$ aliquot from each sample bag was drawn to fill a glass cuvette. The cuvette was placed in a module inside a fluorimeter (Thermo Fisher Scientific Inc., FM109515, Waltham, MA, USA). The excitation and emission wavelength filters were 440 and 500 nm, respectively. The amount of tracer at each distance was divided by the collector area and the results were expressed in $\eta \mathrm{g} \mathrm{cm}^{-2}$.

\section{Herbicide efficacy trial}

A efficacy trial was performed in another area, without soybean, in a randomized block design with four replications in a $3 \times 2+1$ factorial scheme, being three herbicide solutions and two carrier volumes ( 75 and $\left.150 \mathrm{~L} \mathrm{ha}^{-1}\right)$. A nontreated check was included only for comparisons. The herbicide solutions were the same used for drift evaluation, as well as the sprayer and operating pressure. The travel speeds to apply 75 and $150 \mathrm{~L}$ ha $^{-1}$ were 8.8 and $4.4 \mathrm{~km} \mathrm{~h}^{-1}$, respectively. A $75 \mathrm{~L}$ $\mathrm{ha}^{-1}$ was used in order to have a better operational efficiency of sprayers. Plot sizes were $5 \times 3 \mathrm{~m}$ establihed in an area with Commelina benghalensis (14 plants $\mathrm{m}^{-2}, 4-6$ leaves), Cenchrus echinatus (12 plants $\mathrm{m}^{-2}, 2$ leaves) and Portulaca oleracea (11 plants $\mathrm{m}^{-2}, 4-6$ leaves) in the moment of the application. Other weed species such as Ipomoea sp., Alternanthera tenella, Amaranthus viridis, and Bidens pilosa were in the area but at lower infestation. The herbicide efficacy was evaluated at 4, 7 e 14 days after application (DAA). Visual rates varied from 1 (poor control) to 6 (excellent control), as described by Alam (1974). An overall grade per plot was applied, since the objective was to compare the application techniques.

Additionaly, a brilliant blue tracer (Duas Rodas, Jaraguá do Sul, Brazil) was added to the solutions at $500 \mathrm{~g} \mathrm{ha}^{-1}$ to evaluate spray deposition on weeds. Once application was performed, all weeds presented in $0.18 \mathrm{~m}^{2}(0.42 \times 0.42 \mathrm{~m})$ at each plot were cut and placed into plastic bag, and then placed in dark to avoid any unexpected photodegradation. Plants were not separated by species given the homogeneity of the area (BUENO et al., 2014).

In laboratory, a $100 \mathrm{~mL}$ of distilled water was added to each plastic bag, which was swirled and shaken manually during $30 \mathrm{~s}$. The samples were left to rest for $24 \mathrm{~h}$ in a refrigerator at $10^{\circ} \mathrm{C}$. A $3 \mathrm{~mL}$ aliquot from each sample bag was drawn to fill a glass cuvette, which was placed in a module inside a spectrophotometer (Biospectro, SP22, Curitiba, PR, Brazil). The wavelength used was $630 \mathrm{~nm}$. The amount of tracer was divided by the dry weight of weeds and the results were expressed in $\mu \mathrm{g} \mathrm{g}^{-1}$. The weeds were dried at $65^{\circ} \mathrm{C}$ during $72 \mathrm{~h}$.

\section{Droplet spectrum and physicochemical properties}

Droplet spectrum of herbicide solutions produced through AIXR nozzles was evaluated using water-sensitive papers with dimensions of 76 x $26 \mathrm{~mm}$ (Spraying Systems Co., Wheaton, USA). Previously the applications in efficacy trials, one sensitive paper was placed at horizontal position in each plot. The papers were then scanned using a digital scanner (HP Co., Scanjet 2400, Palo Alto, USA) at 600 dpi non-interpoled resolution, 24-bit colors, and bitmap format, analyzed using e-Sprinke Software (Ablevision, São Carlos, SP, Brazil). Spray parameters of interest were volumetric median diameter (VMD), relative span (RS), volume percentage of droplets smaller than $150 \mu \mathrm{m}$ $\left(\mathrm{V}_{150}\right)$, and coverage (droplet $\mathrm{cm}^{-2}$ and percent area).

Among physicochemical properties, surface tension, potential hidrogenionic $(\mathrm{pH})$, dynamic viscosity, and electrical conductivity were characterized using four replications of herbicide solutions sprayed in efficacy trials. Surface tension was quantified using a tensiometer (Kruss, K6, Hamburg, Germany), following the du Nouy ring methodology (LUNKENHEIMER; WANTKE, 1981). Electrical conductivity and $\mathrm{pH}$ were measured using a portable $\mathrm{pH} /$ conductivity meter (Hanna, HI98139, Woonsocket, USA). Viscosity was determined using a rotary microprocessed viscometer (Quimis, 860M21, Diadema, SP, Brazil).

\section{Statistical analysis}

Firstly, the data were submitted to assumption analysis using SPSS Software, version 20.0 (SPSS Inc., Chicago, IL, USA). Homogeneity of variance and additivity of blocks were analyzed using Levene and Tukey's tests, respectively. Normality of residuals was analyzed using Shapiro Wilk or Kolmogorov-Smirnov's tests, depending on sample size of each variable. Data were transformed by $(\mathrm{x})^{0.5}$, except $\mathrm{V}_{150}$ data, which were transformed by arc sine $\left[(\mathrm{x} / 100)^{0.5}\right]$. Afterwards, they were subjected to analysis of variance using Sisvar Statistical Software, version 5.6 (Sisvar, Lavras, MG, Brazil). Averages from qualitative factors were compared using Tukey's test, whereas from quantitative factors were subject to regression analysis using SigmaPlot, version 11.0 (Systat 
Software Inc., Chicago, IL, USA). All analysis were performed at $\alpha=0.05$.

\section{RESULTS AND DISCUSSION}

Droplet spectrum did not depend on the interaction between solution and carrier volume. The addition of adjuvants in HS did not modify the VMD, $\mathrm{V}_{150}$, and coverage in sensitive papers, varying from 455 to $548 \mu \mathrm{m}, 1.62$ to $2.22 \%$, and 18.4 to $19.0 \%$, respectively. The addition of fae in
ALVES et al.

HS produced a more heterogeneous droplet spectrum than HS alone or with sles. Among the coverage, VMD, RS, $\mathrm{V}_{150}$, surface tension and hidrogenionic potential, the carrier volume only had effects on coverage (Tables 2 and 3). As expected, $75 \mathrm{~L} \mathrm{ha}^{-1}$ had lower coverage than $150 \mathrm{~L} \mathrm{ha}^{-1}$. When the carrier volume was increased from 75 to $150 \mathrm{~L}$ $\mathrm{ha}^{-1}$, an increment of $56 \%$ and $73 \%$ on coverage was observed, in percentage and in droplets $\mathrm{cm}^{-2}$ (respectively). It suggests that double the carrier volume does not necessarily double the coverage.

Table 2. Droplet spectrum generated in applications of glyphosate + 2,4-D solutions through AIXR 110015 nozzles using two carrier volumes.

\begin{tabular}{|c|c|c|c|c|c|}
\hline Solution & VMD & $\mathrm{RS}$ & $\mathrm{V}_{150}$ & Coverage & \\
\hline & --- $\mu \mathrm{m}---$ & & ----\%--- & --drop $\mathrm{cm}^{-2}--$ & -----\%---- \\
\hline HS & $543 \mathrm{a}$ & $1.05 \mathrm{a}$ & $2.06 \mathrm{a}$ & $78.34 \mathrm{a}$ & $18.38 \mathrm{a}$ \\
\hline HS + sles & $548 \mathrm{a}$ & $1.06 \mathrm{a}$ & $1.62 \mathrm{a}$ & $72.27 \mathrm{a}$ & $18.50 \mathrm{a}$ \\
\hline $\mathrm{HS}+\mathrm{fae}$ & $455 \mathrm{a}$ & $1.36 \mathrm{~b}$ & $2.22 \mathrm{a}$ & $79.39 \mathrm{a}$ & $19.02 \mathrm{a}$ \\
\hline LSD & 172 & 0.25 & 1.29 & 28.43 & 9.12 \\
\hline \multicolumn{6}{|c|}{ Carrier volume } \\
\hline$---\mathrm{L} \mathrm{ha}^{-1}--$ & & & & & \\
\hline 75 & $557 \mathrm{a}$ & $1.12 \mathrm{a}$ & $1.80 \mathrm{a}$ & $56.04 \mathrm{~b}$ & $14.50 \mathrm{~b}$ \\
\hline 150 & $473 \mathrm{a}$ & $1.19 \mathrm{a}$ & $2.14 \mathrm{a}$ & $97.29 \mathrm{a}$ & $22.77 \mathrm{a}$ \\
\hline LSD & 115 & 0.17 & 0.87 & 19.04 & 6.11 \\
\hline CV (\%) & 25.71 & 16.63 & 50.56 & 28.54 & 37.66 \\
\hline $\mathrm{F}_{\mathrm{sol}}$ & $1.238^{\mathrm{ns}}$ & $6.748^{*}$ & $0.776^{\mathrm{ns}}$ & $0.246^{\mathrm{ns}}$ & $0.019^{\mathrm{ns}}$ \\
\hline $\mathrm{F}_{\mathrm{v}}$ & $2.395^{\mathrm{ns}}$ & $0.719^{\mathrm{ns}}$ & $0.706^{\mathrm{ns}}$ & $21.327^{*}$ & $8.341^{*}$ \\
\hline $\mathrm{F}_{\mathrm{sol} \mathrm{x} \mathrm{v}}$ & $0.270^{\mathrm{ns}}$ & $0.213^{\mathrm{ns}}$ & $0.003^{\mathrm{ns}}$ & $0.433^{\text {ns }}$ & $0.195^{\mathrm{ns}}$ \\
\hline
\end{tabular}

Averages followed by the same letter in the column, within solution and carrier volume, do not differ using Tukey's test at $\alpha=0.05$.

VMD: volumetric median diameter; RS: relative span; $\mathrm{V}_{150}$ : volume percentage of droplets finer than $150 \mu \mathrm{m}$.; ${ }^{1} \mathrm{HS}$ : glyphosate $+2,4-\mathrm{D}$; sles: sodium lauryl ether sulphate; fae: fatty acid esters; LSD: least significant difference; $C V$ : coefficient of variation; $F_{s o l}, F_{v}, F_{s o l} x$ : Calculated F-value for solution, carrier volume and interaction between both factors. *Significant at $\alpha=0.05$. ${ }^{\text {ns }}$ Non-significant.

Table 3. Surface tension and hidrogenionic potential of glyphosate $+2,4-\mathrm{D}$ solutions prepared using two carrier volumes.

\begin{tabular}{lll}
\hline Solution & Surface tension & $\mathrm{pH}$ \\
\hline $\mathrm{HS}$ & $----\mathrm{mN} \mathrm{m}^{-1}----$ & \\
$\mathrm{HS}+$ sles & $30.37 \mathrm{~b}$ & $5.541 \mathrm{a}$ \\
$\mathrm{HS}+\mathrm{fae}$ & $31.62 \mathrm{a}$ & $5.544 \mathrm{a}$ \\
\hline LSD & $29.25 \mathrm{c}$ & $5.541 \mathrm{a}$ \\
\hline Carrier volume & 0.67 & 0.012 \\
\hline$---\mathrm{L} \mathrm{ha}{ }^{-1}---$ & & \\
75 & & \\
150 & $30.50 \mathrm{a}$ & $5.542 \mathrm{a}$ \\
\hline LSD & $30.33 \mathrm{a}$ & $5.542 \mathrm{a}$ \\
\hline CV $(\%)$ & 0.45 & 0.008 \\
$\mathrm{~F}_{\text {sol }}$ & 1.73 & 0.18 \\
$\mathrm{~F}_{\mathrm{v}}$ & $40.650^{*}$ & $0.174^{\mathrm{ns}}$ \\
$\mathrm{F}_{\text {sol x }}$ & $0.600^{\mathrm{ns}}$ & $0.043^{\mathrm{ns}}$ \\
\hline
\end{tabular}

Averages followed by the same letter in the column, within solution and carrier volume, do not differ using Tukey's test at $\alpha=0.05$.

${ }^{1}$ HS: glyphosate + 2,4-D; sles: sodium lauryl ether sulphate; fae: fatty acid esters; LSD: least significant difference; CV: coefficient of variation; $\mathrm{F}_{\mathrm{sol}}, \mathrm{F}_{\mathrm{v}}, \mathrm{F}_{\mathrm{sol} \text { x }}$ : Calculated $\mathrm{F}$-value for solution, carrier volume and interaction between both factors. *Significant at $\alpha=0.05$.

${ }^{\mathrm{ns}}$ Non-significant. 
As observed for droplet spectrum, the surface tension and $\mathrm{pH}$ also did not depend on the interaction between solution and carrier volume. The HS with or without the adjuvants had similar $\mathrm{pH}$, but differences on surface tension were observed (Table 3). The HS with fae had the lowest surface tension $\left(29.25 \mathrm{mN} \mathrm{m}^{-1}\right)$, whereas the highest value was produced by HS with sles $\left(31.62 \mathrm{mN} \mathrm{m}^{-}\right.$ $\left.{ }^{1}\right)$. The addition of sodium lauryl adjuvant in readymixed solution surprisingly increased the surface tension in relation to HS alone, but the difference was not so big. It was expected a reduction because this adjuvant is a surface-active agent in most cases. It is important to highlight that the HS without adjuvants already had a small suface tension, demostrating that the herbicide formulation had surfactant in its composition.

Surface tension has relation with droplet size, expecting coarser droplets from solutions with greater surface tensions However, those differences were not big enough to effect the VMD. According to Butler Ellis and Tuck (2000), a decrease in the surface tension often produce coarser sprays when atomized through air-induction nozzles, such as the nozzle type used in this study. The effect of the surface tension on the spray droplet size depends on the nozzle type, physicochemical properties of solution, including adjuvants, which interact differently depending on pesticide solution and nozzle type (BUTLER ELLIS; TUCK, 1999; HILZ; VERMEER, 2013; MILLER; BUTLER ELLIS, 2000).

Dynamic viscosity and electrical conductivity depended on the interaction between solution and carrier volume (Tables 4 and 5). The HS alone and HS + fae solutions had greater dynamic viscosity at $75 \mathrm{~L} \mathrm{ha}^{-1}$ than at $150 \mathrm{~L} \mathrm{ha}^{-1}$ (Table 4). At $75 \mathrm{~L} \mathrm{ha}^{-1}$, the addition of fatty acid esters adjuvant to HS reduced the viscosity in relation to the other solutions. At $150 \mathrm{~L} \mathrm{ha}^{-1}$, sodium lauryl adjuvant increased the viscosity of solution; however, it did not increase the VMD or reduced the $\mathrm{V}_{150}$. Although Hazen (2004) reported that viscosity may induce the formation of coarse sprays by shifting the droplet size distribution to a larger size, it was not observed in this study.

Table 4. Dynamic viscosity of glyphosate $+2,4-\mathrm{D}$ solutions prepared using two carrier volumes.

\begin{tabular}{|c|c|c|c|c|}
\hline Carrier volume & $\begin{array}{l}\text { Solution } \\
\text { HS }\end{array}$ & HS + sles & $\mathrm{HS}+\mathrm{fae}$ & Average \\
\hline ---L ha ${ }^{-1}---$ & 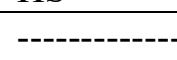 & $----m P a ~ s--$. & ------- & \\
\hline 75 & $0.900 \mathrm{aA}$ & $0.900 \mathrm{aA}$ & $0.820 \mathrm{bA}$ & 0.873 \\
\hline 150 & $0.702 \mathrm{bB}$ & $0.950 \mathrm{aA}$ & $0.662 \mathrm{bB}$ & 0.772 \\
\hline Average & 0.801 & 0.925 & 0.741 & \\
\hline $\mathrm{CV}(\%)$ & 4.60 & & & \\
\hline $\mathrm{LSD}_{\mathrm{sol}}$ & 0.068 & & & \\
\hline $\mathrm{LSD}_{\mathrm{v}}$ & 0.056 & & & \\
\hline \multicolumn{5}{|c|}{$\mathrm{F}_{\mathrm{sol}}=46.098^{*} ; \mathrm{F}_{\mathrm{v}}=43.351 * ; \mathrm{F}_{\text {sol x v }}=24.679 *$} \\
\hline
\end{tabular}

Table 5. Electrical conductivity of glyphosate $+2,4-\mathrm{D}$ solutions prepared using two carrier volumes.

\begin{tabular}{|c|c|c|c|c|}
\hline Carrier volume & $\begin{array}{l}\text { Solution } \\
\text { HS }\end{array}$ & $\mathrm{HS}+$ sles & $\mathrm{HS}+\mathrm{fae}$ & Average \\
\hline ---L ha ${ }^{-1}---$ & 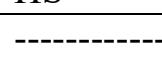 & $\mu \mathrm{S} \mathrm{cm}^{-1}$ & 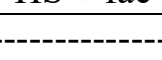 & \\
\hline 75 & $9.59 \mathrm{bA}$ & $9.65 \mathrm{aA}$ & $9.60 \mathrm{bA}$ & 9.62 \\
\hline 150 & $5.49 \mathrm{aB}$ & $5.32 \mathrm{bB}$ & $5.13 \mathrm{cB}$ & 5.31 \\
\hline Average & 7.54 & 7.48 & 7.36 & \\
\hline CV (\%) & 0.18 & & & \\
\hline $\mathrm{LSD}_{\mathrm{sol}}$ & 0.02 & & & \\
\hline $\mathrm{LSD}_{\mathrm{v}}$ & 0.02 & & & \\
\hline \multicolumn{5}{|c|}{$\mathrm{F}_{\mathrm{sol}}=379.815^{*} ; \mathrm{F}_{\mathrm{v}}=645666.677^{*} ; \mathrm{F}_{\mathrm{sol} \mathrm{xv}}=416.105^{*}$} \\
\hline
\end{tabular}


The carrier volume of $75 \mathrm{~L} \mathrm{ha}^{-1}$ produced higher electrical conductivity than at $150 \mathrm{~L} \mathrm{ha}^{-1}$, which is explainable for having a higher product concentration. At $75 \mathrm{~L} \mathrm{ha}^{-1}$, HS + sles had the highest value of conductivity $\left(9.65 \mu \mathrm{S} \mathrm{cm} \mathrm{cm}^{-1}\right)$, whereas at $150 \mathrm{~L} \mathrm{ha}^{-1}$, the highest value was observed for HS alone $\left(5.49 \mu \mathrm{S} \mathrm{cm} \mathrm{cm}^{-1}\right)$. This physicochemical property may not have direct effects on droplet spectrum, but herbicide efficacy depends on it. High levels of electrical conductivity mean that there are more total dissolved solids in the solution, and herbicides not dissociated are more readily absorbed by plant foliage than those that dissociate (OSU, 2017), but it does not necessarily reduce herbicide efficacy.

No interaction between solution and carrier volume was observed for depositon of tracer on weeds (Table 6). Both carrier volumes produced similar depositon, varying from 891 to $1009 \mu \mathrm{g} \mathrm{g}^{-1}$. Comparing the solutions, the HS + sles produced higher deposition than HS + fae; however, both solutions produced similar depositon when compared to HS alone. As consequence, herbicide solutions and carrier volumes did not influence weed control at 4, 7, and 14 days after application (Figures 1 and 2). For both factors, the control rates ranged from 2 to 3 at 4 DAA, reaching the maximum of 5 to 6 at 14 DAA. It is important to highlight that a general evaluation was done for each plot. Moreover, there were no herbicideresistant plants in the report of the area. Different results can be obtained with different weed species.

Table 6. Deposition of tracer on weeds from glyphosate + 2,4-D applications through AIXR 110015 nozzles using four solution types and two carrier volumes.

\begin{tabular}{|c|c|c|c|c|}
\hline Carrier volume & $\begin{array}{l}\text { Solution } \\
\text { HS }\end{array}$ & HS + sles & $\mathrm{HS}+\mathrm{fae}$ & Average \\
\hline$---\mathrm{L} \mathrm{ha}^{-1}---$ & |-------- & $\mu \mathrm{g} \mathrm{g}^{-1}$ & 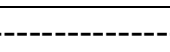 & \\
\hline 75 & 778 & 1433 & 818 & $1009 \mathrm{~A}$ \\
\hline 150 & 1050 & 958 & 664 & $891 \mathrm{~A}$ \\
\hline Average & $914 \mathrm{ab}$ & $1196 \mathrm{a}$ & $741 \mathrm{~b}$ & \\
\hline CV (\%) & 34.07 & & & \\
\hline $\mathrm{LSD}_{\text {sol }}$ & 420 & & & \\
\hline $\mathrm{LSD}_{\mathrm{v}}$ & 282 & & & \\
\hline \multicolumn{5}{|c|}{$\mathrm{F}_{\mathrm{sol}}=4.014^{*} ; \mathrm{F}_{\mathrm{v}}=0.807^{\mathrm{ns}} ; \mathrm{F}_{\mathrm{sol} \mathrm{x} \mathrm{v}}=2.675^{\mathrm{ns}}$} \\
\hline
\end{tabular}

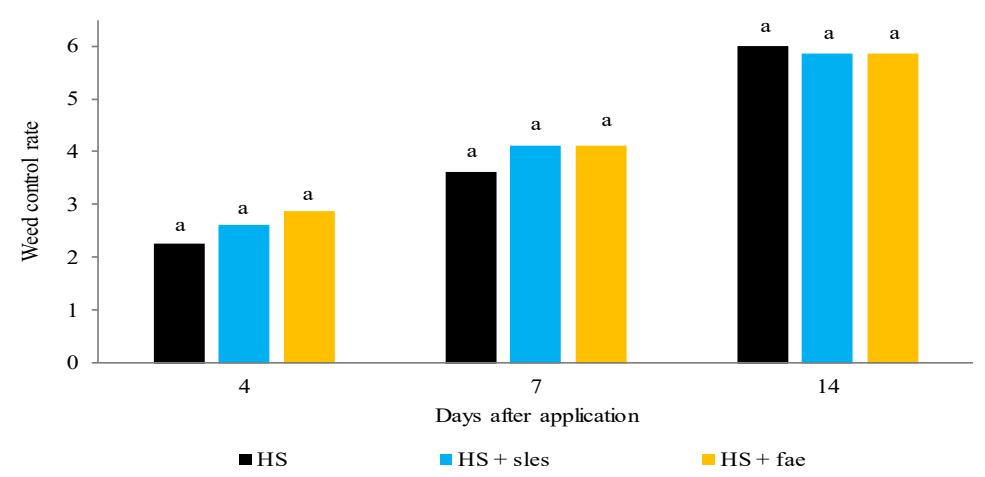

Figure 1. Effect of glyphosate +2,4-D solutions on weed control at 4, 7 and 14 days after application through AIXR 11015 nozzles.

Bars with the same letter, within day after application, do not differ using Tukey's test at $\alpha=0.05$. HS: glyphosate $+2,4-\mathrm{D}$; sles: sodium lauryl ether sulphate; fae: fatty acid esters. 


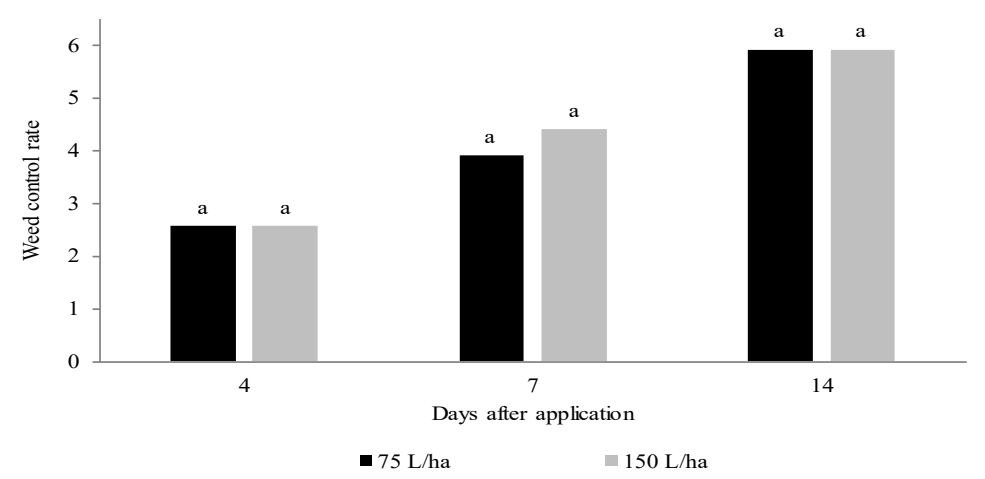

Figure 2. Carrier volume effect on weed control at 4, 7 and 14 days after glyphosate $+2,4-\mathrm{D}$ applications through AIXR 11015 nozzles.

Bars with the same letter, within day after application, do not differ using Tukey's test at $\alpha=0.05$.

Although a lower percentage of coverage at $75 \mathrm{~L} \mathrm{ha}^{-1}$ was observed (Table 2), the herbicide concentration in solution is twice higher than at 150 $\mathrm{L} \mathrm{ha}{ }^{-1}$. In this case, when systemic herbicides are used, such as glyphosate and 2,4-D, the coverage is not very important as much as for contact herbicides. Those results show that it is possible reduce carrier volume without reducing weed control in glyphosate $+2,4-\mathrm{D}$ applications. In addition, Sterling (1994) reported that glyphosate absorption involves a passive diffusion mechanism at high concentrations (absorption increases when external glyphosate concentration increases), which may also improve its efficacy using lower carrier volumes. Nevertheless, drift potential should also be evaluated using lower carrier volumes.

Bueno et al. (2013) evaluated the effects of spray volumes and adjuvants on weed control using glyphosate sprayed through Turbo Teejet nozzles (TT 11002). The authors also observed similar glyphosate efficacy at 30,60 , and $150 \mathrm{~L} \mathrm{ha}^{-1}$, with or without the adjuvant nonyl phenol ethoxylate in solution. They observed better depositions of tracer on weeds using the lowest carrier volumes, differently observed in this study.

No interaction between solution and distance was observed for depositon of tracer on drift collectors (Table 7). The HS, alone or with adjuvants, produced similar depositon regardless of distance, ranging in average from 49.8 to $82.1 \mu \mathrm{g} \mathrm{g}^{-}$ ${ }^{1}$. Costa et al. (2014) also did not verify effects of adjuvants on glyphosate $+2,4-\mathrm{D}$ spray drift collected at 5 and $10 \mathrm{~m}$ in field applications using a $11 \mathrm{~m}$ boom sprayer. Gandolfo et al. (2012) evaluated the drift from glyphosate and 2,4-D applications in a wind tunnel, using $100 \mathrm{~L} \mathrm{ha}^{-1}$ carrier volume and AXI 110015 non-air induction flat-fan nozzles. Their results showed that the herbicides with and without phosphatidylcholine + propionic acid adjuvant produced similar drift at 10 $\mathrm{m}$ downwind, but the adjuvant reduced drift at $5 \mathrm{~m}$. Although the authors used a different source of glyphosate, nozzle type and carrier volume, there is a similar trend with results found in this study. In both cases, the adjuvants did not reduce the drift at $10 \mathrm{~m}$.

Table 7. Deposition of tracer on drift collectors after glyphosate +2 ,4-D applications through AIXR 110015 nozzles.

\begin{tabular}{lllll}
\hline \multirow{2}{*}{ Distance } & Solution & HS + sles & HS + fae & Average \\
\hline--- m--- & HS & ------------------ & \\
1 & 136.1 & 162.9 & 237.5 & 178.9 \\
2 & 57.6 & 67.4 & 74.8 & 66.6 \\
3 & 28.1 & 37.6 & 44.6 & 36.8 \\
5 & 18.1 & 23.3 & 42.2 & 27.9 \\
10 & 8.9 & 7.3 & 11.6 & 9.3 \\
\hline Average & $49.8 \mathrm{a}$ & $59.7 \mathrm{a}$ & $82.1 \mathrm{a}$ &
\end{tabular}

$\mathrm{F}_{\text {sol } \mathrm{x} \text { dist }}=1.38^{\mathrm{ns}} ; \mathrm{F}_{\text {sol }}=1.02^{\mathrm{ns}} ; \mathrm{F}_{\text {dist }}=3,28^{*}$

Averages followed by the same letter in the rows do not differ using Tukey's test at $\alpha=0.05$; ${ }^{1} \mathrm{HS}$ : glyphosate $+2,4-\mathrm{D}$; sles: sodium lauryl ether sulphate; fae: fatty acid esters; $\mathrm{F}_{\text {sol }}, \mathrm{F}_{\text {dist }}, \mathrm{F}_{\text {sol x dist }}$ : Calculated F-value for solution, distance and interaction between solution and distance. *Significant at $\alpha=0.05 .{ }^{\text {ns }}$ Non-significant. 
Deposits of tracer on drift collectors were reduced exponentially in applications of glyphosate
$+2,4-\mathrm{D}$ as distance from sprayed area increased regardless of spray composition (Figure 3).

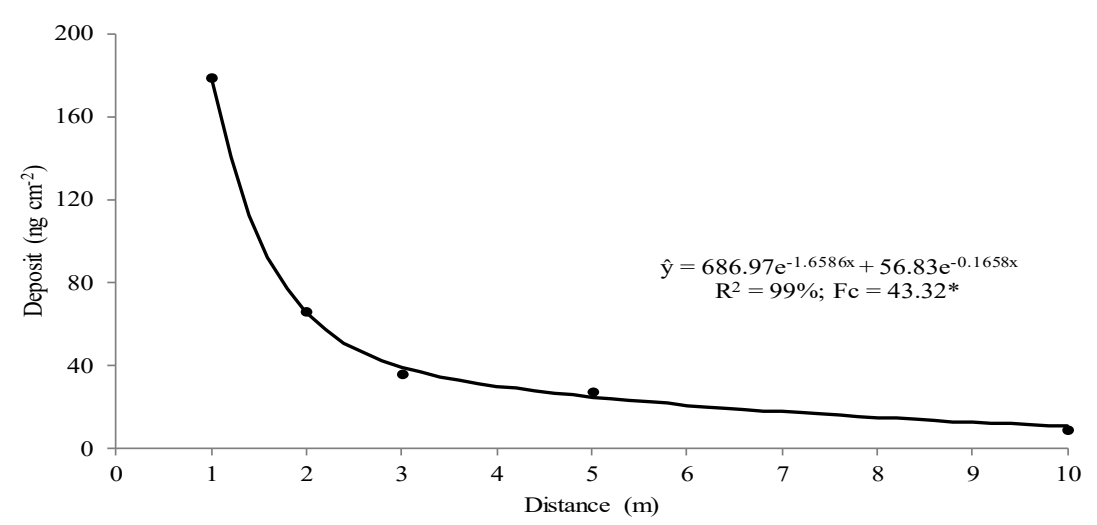

Figure 3. Curve fitting and regressions for tracer deposits at downwind distances in glyphosate +2 ,4-D applications through AIXR 110015 nozzles.

Fc: Calculated F-value.

\section{CONCLUSIONS}

Glyphosate + 2,4-D with or without adjuvants, sprayed using 75 or $150 \mathrm{~L} \mathrm{ha}^{-1}$, resulted, in a general way, in similar deposition of tracer on evaluated weeds and their control. It suggests that it is possible reduce carrier volume without reducing weed control in their applications. More studies are necessary for different weed species, especially those with a history of resistance to evaluated herbicides.

Glyphosate + 2,4-D with or without adjuvants, produced similar VMD, V150, and deposition of tracer on drift collectors. Drift reduced exponentially as downwind distance increased, regarless of herbicide solution. It indicates that the adjuvants sodium lauryl ether sulphate and fatty acid esters did not decrease the drift at the tested conditions.

RESUMO: As plantas daninhas são um dos principais fatores que afetam a produção de oleaginosas. Seu manejo tem sido baseado no controle químico com herbicidas, como o glifosato e o 2,4-D, devido ao amplo espectro de controle e eficiência das aplicações. Contudo, seu uso deve ser feito corretamente para reduzir a deriva nas pulverizações. Portanto, este estudo teve como objetivo avaliar a eficácia e a deriva da pulverização a partir de aplicações de glifosato e 2,4-D em mistura com adjuvantes. A avaliação de deriva foi realizada em parcelas subdivididas em delineamento de blocos casualizados com cinco repetições. As parcelas principais consistiram de três soluções herbicidas a $150 \mathrm{~L} \mathrm{ha}^{-1}$ (glifosato $+2,4-\mathrm{D}$, glifosato + 2,4-D + lauril éter-sulfato de sódio e glifosato $+2,4-\mathrm{D}+$ ésteres de ácidos graxos). As sub-parcelas consistiram em cinco distâncias a favor do vento $(1 \mathrm{a} 10 \mathrm{~m})$ da área pulverizada. Utilizou-se um traçador para ser detectado por fluorimetria e coletores de deriva. O ensaio de eficácia foi conduzido em delineamento de blocos casualizados com quatro repetições, em esquema fatorial $3 \times 2$, sendo as mesmas soluções herbicidas e duas taxas de aplicação (75 e $150 \mathrm{~L} \mathrm{ha}^{-1}$ ). O espectro de gotas e o depósito nas plantas daninhas foram avaliados e as propriedades físico-químicas das soluções herbicidas foram caracterizadas. Glifosato + 2,4-D, com ou sem adjuvantes, pulverizados com 75 ou $150 \mathrm{~L} \mathrm{ha}^{-1}$, resultaram em deposição similar do traçador em plantas daninhas, bem como controles equivalentes. Esses herbicidas associados ou não ao lauril éter-sulfato de sódio e aos ésteres de ácidos graxos produziram espectro de gotas e deposição do traçador em coletores de deriva semelhantes.

PALAVRAS-CHAVE: Adjuvantes. Herbicida. Tecnologia de aplicação. 


\section{REFERENCES}

ALAM, Asociación Latinoamericana de Malezas. Recomendaciones sobre unificación de los sistemas de evaluación en ensayos de control de malezas. ALAM, Bogotá, v.1, p.35-38, 1974.

BUENO, M. R.; ALVES, G. S.; PAULA, A. D. M.; CUNHA, J. P. A. R. Volumes de calda e adjuvante no controle de plantas daninhas com glyphosate. Planta Daninha, Viçosa, v. 31, n. 3, p. 705-713, 2013. https://doi.org/10.1590/S0100-83582013000300022

BUENO, M. R.; CUNHA, J. P. A. R.; NAVES, M. G.; TAVARES, R. M. Deposição de calda e controle de plantas daninhas empregando pulverizador de barra convencional e com barra auxiliar, em volumes de calda reduzidos. Planta Daninha, Viçosa, v. 32, n. 2, p. 447-454, 2014 . https://doi.org/10.1590/S010083582014000200023

BUTLER ELLIS, M. C.; TUCK, C. R. How adjuvants influence spray formation with different hydraulic nozzles. Crop Protection, London, v.18, p.101-110, 1999. https://doi.org/10.1016/S0261-2194(98)00097-0

BUTLER ELLIS, M. C.; TUCK, C. R. The variation in characteristics of air induction sprays with adjuvants. Aspects of Applied Biology, Guildford, v.53, p.155-162, 2000.

COSTA, A. G. F.; VELINI, E. D.; ROSSI, C. V. S.; CORRÊA, M. R.; NEGRISOLI, E.; FIORINI, M. V.; SIONO, L. M. Adjuvantes na deriva de 2,4-D + glyphosate em condições de campo. Ciência Rural, Santa Maria, v.44, n.3, p.387-392, 2014. https://doi.org/10.1590/S0103-84782014000300001

CUNHA, J. P. A. R.; ALVES, G. S.; MARQUES, R. S. Tensão superficial, potencial hidrogeniônico e condutividade elétrica de caldas de produtos fitossanitários e adjuvantes. Revista Ciência Agronômica, Fortaleza, v.48, p.261-270, 2017.

GANDOLFO, M. A.; MORAES, E. D.; GANDOLFO; U. D.; OSIPE, J. B.; RODRIGUES, E. B.; OSIPE, R. Potencial de deriva da mistura de 2,4-D com glyphosate. Revista Brasileira de Herbicidas, Londrina, v.11, n.3, p.332-338, 2012. https://doi.org/10.7824/rbh.v11i3.192

HAZEN, J. L. Spray drift experiments with ADSEE_ethyl hydroxyethyl cellulose as a tank mix adjuvant e part one: viscosity and atomization. In: Proceedings of 7th International Symposium on Adjuvants for Agrochemicals (ISAA 2004), Cape Town, South Africa, p.105-114, 2004.

HILLOCKS, R. J. Farming with fewer pesticides: EU pesticide review and resulting challenges for UK agriculture. Crop Protection, London, v. 31, n. 1, p. 85-93. 2012. https://doi.org/10.1016/j.cropro.2011.08.008

HILZ; E.; VERMEER, A. W. P. Spray drift review: the extent to which a formulation can contribute to spray drift reduction. Crop Protection, London, v.44, p.75-83, 2013. https://doi.org/10.1016/j.cropro.2012.10.020

JONG, F. M. W.; SNOO, G. R.; ZANDE, J. C. Estimated nationwide effects of pesticide spray drift on terrestrial habitats in the Netherlands. Journal of Environmental Management, Oxford, v. 86, n. 4, p. 721730, 2008. https://doi.org/10.1016/j.jenvman.2006.12.031

LUNKENHEIMER, K.; WANTKE, K. D. Determination of the surface tension of surfactant solutions applying the method of Lecomte du Noüy (ring tensiometer). Colloid and Polymer Science, Darmstadt, v. 259, p. 354366, 1981. https://doi.org/10.1007/BF01524716

MASKI, D.; DURAIRAJ. D. Effects of charging voltage, application speed, target height, and orientation upon charged spray deposition on leaf abaxial and adaxial surfaces. Crop Protection, London, v. 29, n.2, p. 134141, 2010. https://doi.org/10.1016/j.cropro.2009.10.006 
MILLER, P. C. H.; BUTLER ELLIS, M. C. Effects of formulation on spray nozzle performance for applications from ground-based boom sprayers. Crop Protection, London, v.19, n.8, p. 609-615, 2000. https://doi.org/10.1016/S0261-2194(00)00080-6

NEPOMUCENO, M.; ALVES, P. L. C. A.; DIAS, T. C. S.; PAVANI, M. C. M. D. Períodos de interferência das plantas daninhas na cultura da soja nos sistemas de semeadura direta e convencional. Planta Daninha, Viçosa, v.25, n.1, p.43-50, 2007. https://doi.org/10.1590/S0100-83582007000100005

OSU, Oregon State University. Water quality effects herbicide efficacy. Available on:

$<\mathrm{http}$ ://oregonstate.edu/dept/nursery-weeds/feature_articles/spray_tank/spray_tank.htm $>$. Accessed on April $20,2017$.

ROBINSON, A. P.; SIMPSON, D. M.; JOHNSON, W. G. Summer annual weed control with 2,4-D and glyphosate. Weed Technology, Cambridge, v.26, p.657-660, 2012. https://doi.org/10.1614/WT-D-12-00081.1

STERLING, T. M. Mechanisms of herbicide absorption across plant membranes and accumulation in plant cells. Weed Science, Cambridge, v.42, p.263-276, 1994. https://doi.org/10.1017/S0043174500080383

TSAI, M. Y.; ELGETHUN, K.; RAMAPRASAD, J.; YOST, M. G.; FELSOT, A. S.; HEBERT, V. R.; FENSKE, R. A. The Washington aerial spray drift study: modeling pesticide spray drift deposition from an aerial application. Atmospheric Environment, Oxford, v.39, n.33, p.6194-6203, 2005.

https://doi.org/10.1016/j.atmosenv.2005.07.011

VERCRUYSSE, F.; STEURBAUT, W. POCER, the pesticide occupational and environmental risk indicator. Crop Protection, London, v.21, p.307-315, 2002. https://doi.org/10.1016/S0261-2194(01)00102-8 